\title{
Trends and hotspots in landscape transformation based on anthropogenic impacts on soil in Hungary, 1990-2018
}

\author{
Szabolcs B ALOGH ${ }^{1}$ and Tibor József NOVÁK ${ }^{1}$
}

\begin{abstract}
The transformation of the landscapes due to the anthropogenic activities is increasing worldwide. These changes are also manifested in the change of soil-forming processes. The land cover (LC) changes evaluated according to their influence on anthropogenic features of soils allows to distinguish between LC changes resulting increased and decreased human impact (HI). In our study, we assess the changes of HI on landscapes and its spatial distribution across Hungary. The changes were evaluated by using LC data of four periods between 1990 and 2018 reclassified based on the related anthropogenic soil features. To identify the hotspots of the changes $1 \times 1$ grids were applied in which the direction (increasing, neutral or decreasing $\mathrm{HI}$ ) and frequency (number of landscape patches with LC changes) of changes were evaluated. In our research, the hotspots were identified over the studied four periods. We point out that the spatial distribution of hotspots is very different. The hotspots of the increased human impact are 2,449 cells $\left(643.0 \mathrm{~km}^{2}\right)$ between 1990 and 2018, and the most of it localized in the Pest Plain (67), Csepel Plain (64) and Nagykálló-Nyírség (60). Most of the multiple hotspots are in the outskirts of Budapest to Kiskunlacháza, Bugyi, Délegyháza. As we examine the decreasing hotspot data we found 1,679 cells $\left(1,524.9 \mathrm{~km}^{2}\right)$ between 1990 and 2018. In largest number, they occur on the Kiskunság Sand Ridge (38), Majsa-Szabadka Sand Ridge (37) and Nagykállói-Nyírség (36). Multiple hotspots are located in settlements Izsák, Ásotthalom, Vatta and Nyírmihályi. Regions with numerous hotspots require special management to moderate its negative consequences on soils to consider both increased anthropisation, but also extensification of land use and their consequences.
\end{abstract}

Keywords: landscape degradation, landscape rewilding, land cover change, soil naturalness changes

Received February 2020; Accepted October 2020.

\section{Introduction}

Soils traditionally are considered a four-dimensional product of five natural soil-forming factors, namely: substrate, climate, topography, vegetation, and time (Forman, R.T.T. 1995). Only in the last decades, human society was considered to add as the sixth effective soil-forming factor (DUDAL, R. 2005; Ellis, E.C. and Ramankutty, N. 2008; Ellis, E.C. et al. 2010). Even though, the soil-forming function of anthropogenic activities cannot be disregarded since the first spread of agricultural land cultivation (Kertész, Á.
2009; BALL, B.C. et al. 2017; BAude, M. et al. 2019). The extent of area affected by the human processes, the intensity, and the diversity of ways how the society modified natural soil bodies is continuously increasing. The contribution of the humankind to soil development seems to be more and more relevant, which is indicated by occurrence and spread of anthropogenic, technogenic soils (BoumA, J. et al. 1998; Antrop, M. 2004). Parallelly, always were regions, where human activity decreased or disappeared for a while, which allowed regeneration, renewal of former disturbed or devastated soils (CEAUşu, S.

\footnotetext{
${ }^{1}$ University of Debrecen, Faculty of Technology and Sciences, Department of Landscape Protection and Environmental Geography, H-4002, Debrecen, Egyetem tér 1, POB 400, Hungary. Corresponding author's e-mail: novak.tibor@science.unideb.hu
} 
et al. 2015; Navarro, L. and Pereira, H. 2015). Globally, less and less part of the surface of the Earth remains, where human society should not be considered as a significant factor of soil-forming. (Bouma, J. et al. 1998; Hill, M. et al. 2002; Antrop, M. 2004; Klijn, J.A. 2004; Csorba, P. and Szabó, Sz. 2009; Dale, V.H. and Kline, K.L. 2013; BALOGH, Sz. et al. 2018).

Spatial pattern and its changes of these opposite processes (like soil anthropization and renewal by natural succession) could be considered as the indicator of the actual land needed by the society. Otherwise, it is a phenomenon which should be compensated, regulated, managed, and planned intentionally by the society (LAMBIN, E.F. et al. 2006; NovÁk, T.J. et al. 2013; LundBerG, A. 2018).

The study aimed to point on the changes of the spatial extent of areas, which are affected by changes in intensity of the human impacts between 1990 and 2018. In our consideration, the "Land Cover" classes (LC) and its changes are related to the grade of the transformation of soils by society. Therefore, analysis of LC and the LC changes allows an estimation of the grade of human transformation of landscapes (INCZE, J. and NovÁK, T.J. 2016; Szilassi, P. et al. 2017; NovÁk, T.J. et al. 2019).

In our research, we supposed that besides of well-known processes of intensification (e.g., soil sealing, construction, degradation of soils), on extent areas LC changes were concluded in the decreased grade of "human impacts" (HI). At these sites, the changes allow a restart of soil development towards a less degraded state (i.e., organic carbon sequestration, recharge of soil nutrients, regeneration of aggregate structure and renewed horizon development). Further, we intended to identify the locations with the highest possible spatial accuracy, where these changes appear, since we consider both increasing and decreasing HI-s on landscapes requires compensatory management by local society. Therefore, a hotspot analysis was carried out, for all four study periods, where we identified single and multiple hotspots - for decreased and increased HI-s.

\section{Data sources and methods}

As the main data source to our analysis, the CORINE Land Cover (CLC) database and the CORINE Land Cover Change (CHA) datasets were applied.

In our study, the status datasets of CLC (1990, 2000, 2006, 2012 and 2018) were applied to calculate the share of re-grouped CLC classes according to the grade of their anthropogenic transformation. The methodology of surveys is standardized as it is described at MARI, L. and MatTÁnYI, Zs. (2002), and Mari, L. 2010. The datasets at a scale of 1:100,000 were applied, on the study area (Hungary) it consists of 32 CLC classes (FÖMI, 2002). The minimum mapping unit for areal objects is $>25 \mathrm{ha}$, and the minimum width of the linear objects is $>100 \mathrm{~m}$. Although only the area elements are identified in the CLC, there are some "linear elements" in it. Due to the differences between two time and layer, we use the CHA datasets. In these, they have mapped the less than 5 ha changes, included the motorway and some road changes. So, the GIS database, which we are created, is extended to the digital road changes. Furthermore, we only have these "linear layers" because of the mapping scale of the CORINE Land Cover Change dataset. The important road impact and the fragmentation are sometimes appeared in the CHA polygons.

Afterwards, the status data time series was complemented by change layers (CHA 19902000, 2000-2006, 2006-2012 and 2012-2018). It allows higher accuracy to identify changes as a comparison of the consecutive status layers (MARI, L. and MATtánYI, Zs. 2002; MARI, L. 2010).

As in our earlier works it was described (NovÁк, T.J. et al. 2013; NovÁк, T.J. and TóTH, Cs.A. 2016; Novák, T.J. and Incze, J. 2018; BALOGH, Sz. et al. 2019) to the CLC classes, the expectable influence on the soil cover was assigned, and the CLC classes were reclassified based on the grade of anthropogenic transformation of the soils, into four groups (Figure 1). One of these groups consists of CLC classes which have not been considered to have soils according to the definition of soil by WRB (World Reference Base). 


\begin{tabular}{|c|c|c|c|c|}
\hline \multicolumn{5}{|c|}{$\begin{array}{c}\text { CORINE LC } \\
\text { land cover polygon } \\
(1990 ; 2000 ; 2006 ; 2012 ; 2018)\end{array}$} \\
\hline \multicolumn{5}{|c|}{$\begin{array}{l}\text { Reclassification based on grade of anthropogenic influences } \\
\text { (indicator: anthropogenic transformation of soil based on WRB diagnostics) }\end{array}$} \\
\hline $\begin{array}{c}\text { Grade of } \\
\text { anthropogenic } \\
\text { transformation }\end{array}$ & No soils (0) & $\begin{array}{l}\text { Natural or closer to } \\
\text { natural soils (1) }\end{array}$ & $\begin{array}{l}\text { Soils with } \\
\text { anthropogenic } \\
\text { features (2) }\end{array}$ & $\begin{array}{l}\text { Anthropogenic soils } \\
\text { (3) }\end{array}$ \\
\hline $\begin{array}{l}\text { Corine land cover } \\
\text { classes }\end{array}$ & $\begin{array}{c}(1.3 .1),(5.1 .1) \\
(5.1 .2)\end{array}$ & $\begin{array}{c}(3.1 .1),(3.1 .2),(3.1 .3), \\
(3.2 .1),(3.2 .4),(3.3 .1), \\
(3.3 .2),(3.3 .3),(3.3 .4), \\
(4.1 .1),(4.1 .2)\end{array}$ & $\begin{array}{l}(2.1 .1),(2.1 .2),(2.1 .3), \\
(2.2 .1),(2.2 .2),(2.3 .1), \\
(2.4 .2),(2.4 .3)\end{array}$ & $\begin{array}{c}(1.1 .1),(1.1 .2),(1.2 .1), \\
(1.2 .2),(1.2 .3),(1.2 .4), \\
(1.3 .2),(1.3 .3),(1.4 .1), \\
(1.4 .2)\end{array}$ \\
\hline
\end{tabular}

Fig. 1. Reclassification of CORINE LC classes based on the expectable anthropogenic transformation of soils

Due to repeated surveys of the CLC data, change layers (CHA) from five different years the spatial extent and share of the groups based on the grade of anthropogenic transformation could be calculated, and therefore the changes in the last three decades over the country can be tracked.

Using this classification, the CHA polygons were also evaluated. Therefore, the anthropogenic transformation grades (according to the Figure 1) of the cover class before and after the LC conversion was considered. In furthermore, we ignored the polygons in which the anthropogenic transformation grade before and after the conversion was falling into the same group. Here the intensity of human impact (HI) remained approximately at the same level in spite of the altered LC class, and the change was evaluated as neutral concerning the anthropogenic transformation grade. Polygons, in which the LC conversion also resulted in an altered grade of $\mathrm{HI}$, were divided into two groups: LC conversions with a) increasing, and b) decreasing HI (Figure 2). This reclassification of CHA polygons was done for all four intervals provided by CHA dataset (1990-2000, 2000-2006, 2006-2012, 2012-2018). The extent and number of polygons showing increas- ing or decreasing $\mathrm{HI}$ were calculated for each above-mentioned time intervals. From each interval, the five most extent LC conversion types resulting increased or decreased $\mathrm{HI}$ were listed for further analysis concerning their consequences to soil resources.

To identify hotspots of increasing and decreasing $\mathrm{HI}$ a grid with $1 \times 1 \mathrm{~km}$ cell size was overlain on the LC change maps, the same grid for each type and period. In every $1 \times 1$ $\mathrm{km}$ grid number of polygons with LC conversions resulting changed intensity of $\mathrm{HI}$ were counted (Figure 3). As we have seen in Figure 3 the number of land cover changes (LCC) polygons are demonstrated. The hotspot methodology was assorted only those cells, which LCC number are in the upper quartile of it (e.g. like in Figure 4. only those which are included 2-6 polygons in the cells). The polygons of LC conversions with unchanged intensity (see Figure 2) of HI were eliminated from later analysis. Separately for the type of change (increasing and decreasing $\mathrm{HI}$ ) and each study period, the basic statistic data of the grid cells were calculated. The upper quartiles of the number of LC change polygons per grid cell were considered to be the lower limit to evaluate a grid cell as a hotspot, i.e., hotspots were consid- 


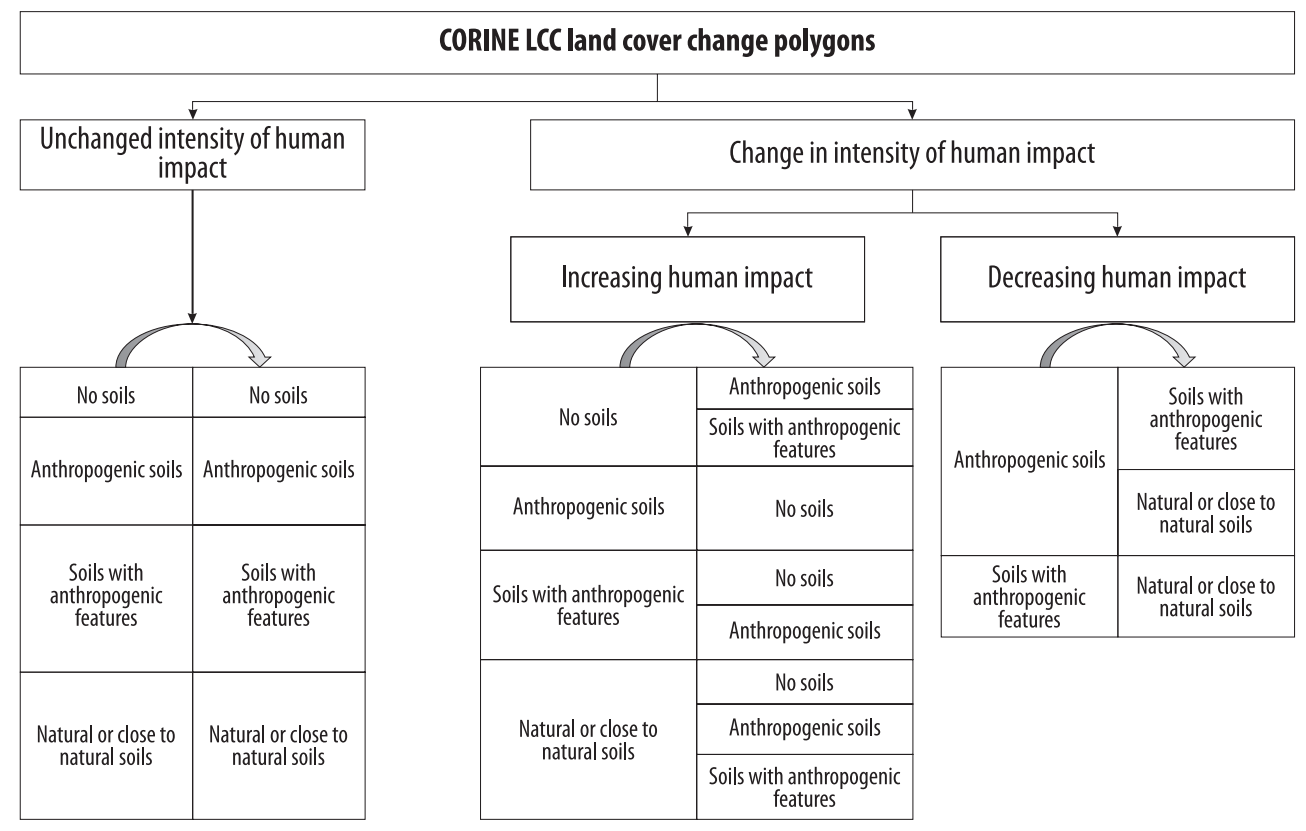

Fig. 2. Evaluations of LC changes based on the expectable change in the intensity of the HI

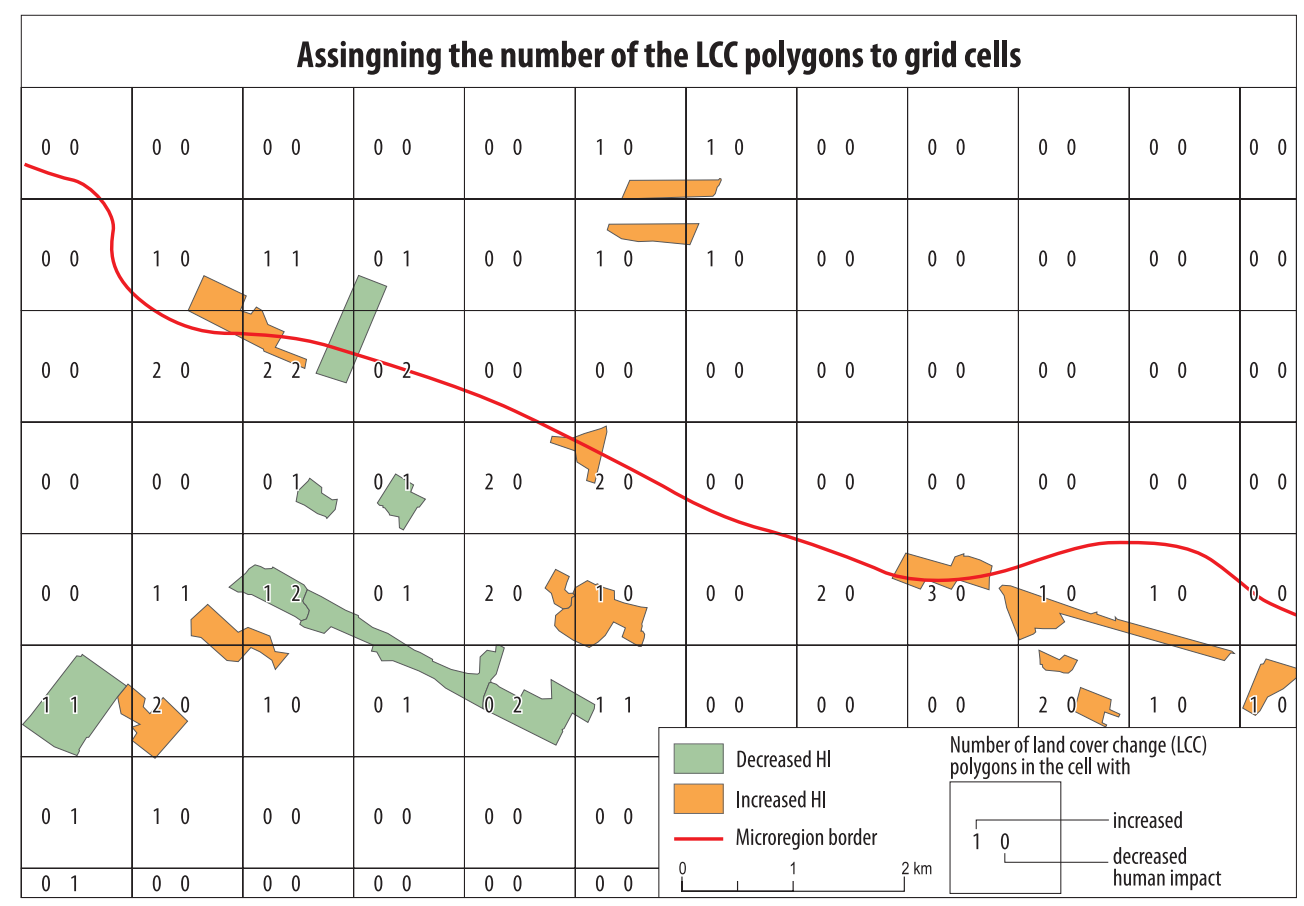

Fig. 3. The method of assigning the LCC polygons to grid cells, for later identification of hotspots 

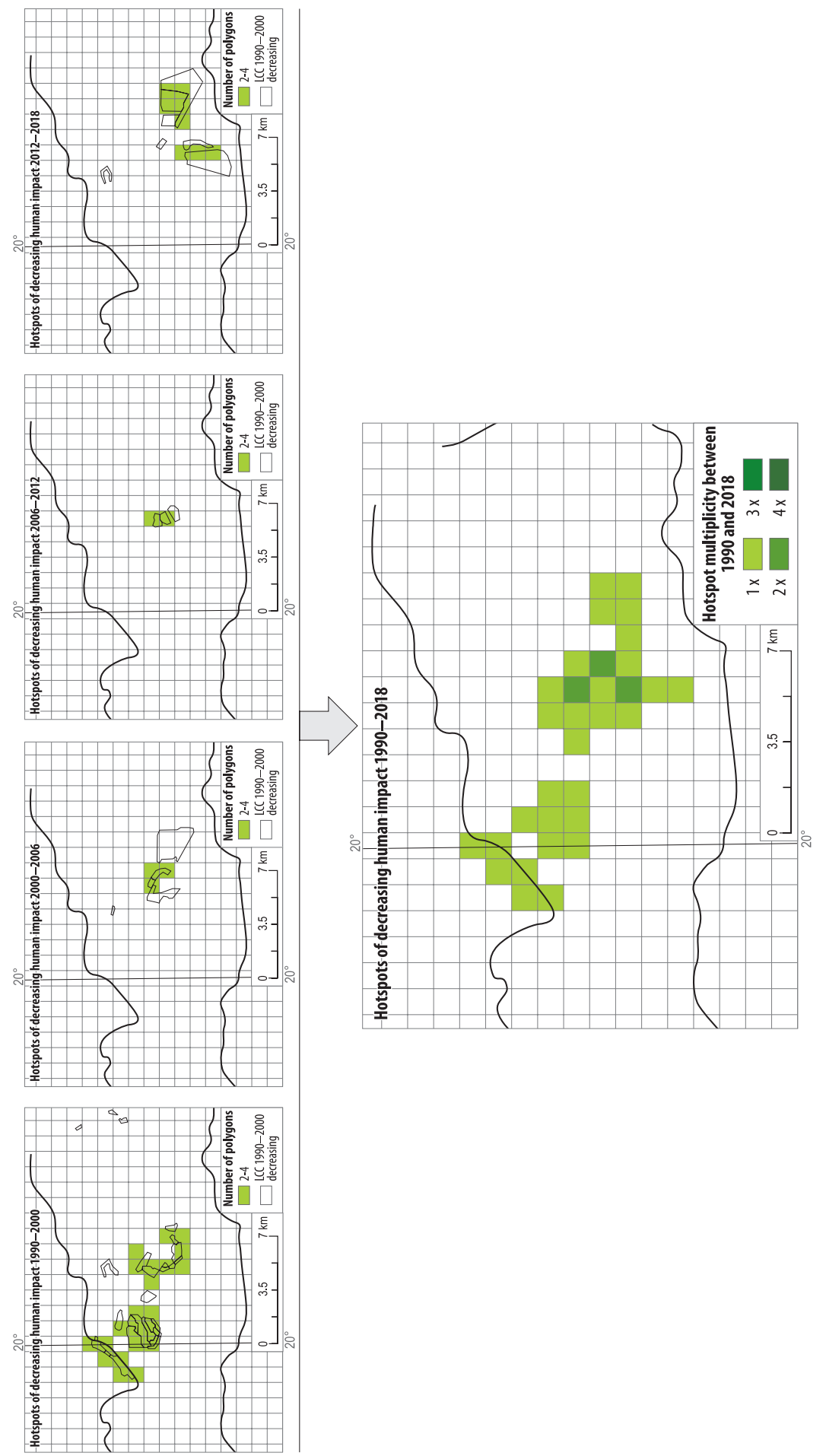
ered those grids, which had higher number of LC change polygons as the upper quartile of the grids for the same period and type of change (Figure 4). If the hotspot lies in the bordel, we attached to that region which is occupied the largest part of the cell.

Hotspots of increasing and decreasing $\mathrm{HI}$ were calculated separately. Further, numerous grids proved to be hotspots not only for one period but in more studied periods. These multiple hotspots for increased and decreased HI were represented with deeper colour intensity on maps.

\section{Results}

\section{Changes of $H I$}

Distribution of LC classes among the groups according to the grade of HI showed slight changes between 1990 and 2018. Most LC classes belong to the group, in which the anthropogenic properties in the soil (disturbance of soil horizons, modification of soil structure, and occurrence of artificial or transported materials) can be recognized. Still, the solum itself is not predominantly a natural product of pedogenic processes. They covered 68.3 per cent of the country in 1990, and their share decreased by 3.2 per cent to 64.9 per cent for 2018 (Table 1).

LC classes, which are related to soils produced completely by the anthropogenic accumulation of transported, relocated or industrially produced materials ('anthropogenic soils' - Table 1) occupied 5.5 per cent in 1990 and their share increased by 0.8 per cent up to 6.3 per cent until 2018. LC classes, in which soil development and horizonation are driven by meanly natural processes (succession of vegetation, topography, and climate) was 24.3 per cent and increased by 2.5 per cent in 2018 up to 26.8 per cent. These changes indicate that share of moderately anthropized soils is only decreasing, and both extreme: anthropization and renaturation of soils affect an increased area. Anyway, anthropization (LC changes with increased HI) affected smaller part of the surface between 1990 and 2018, than LC changes with a decrease of HI.

We also considered the total extent (area, $\mathrm{km}^{2}$ ) and the number of polygons with changed LC class related to increased and decreased human influence separated for the four study periods (Table 2).

Generally, LC change polygons with increased HI had a smaller total area and a higher number in every period. The averaged area of these polygons varied between 0.24 $\mathrm{km}^{2}$ (2012-2018) and $0.29 \mathrm{~km}^{2}$ (2000-2006).

Table 2. Extent and number of land cover change polygons with decreased and increased human influence between 1990 and 2018 in Hungary

\begin{tabular}{|c|c|c|c|c|}
\hline \multirow{4}{*}{ Period } & \multicolumn{4}{|c|}{ Land cover changes with } \\
\hline & \multicolumn{2}{|c|}{$\begin{array}{l}\text { decreased human } \\
\text { influence }\end{array}$} & \multicolumn{2}{|c|}{$\begin{array}{l}\text { increased human } \\
\text { influence }\end{array}$} \\
\hline & \multicolumn{4}{|c|}{ Total } \\
\hline & $\begin{array}{l}\text { area, } \\
\mathrm{km}^{2}\end{array}$ & number & $\begin{array}{l}\text { area, } \\
\mathrm{km}^{2}\end{array}$ & number \\
\hline 1990-2000 & 401.1 & 593 & 185.9 & 677 \\
\hline 2000-2006 & 483.7 & 447 & 189.6 & 651 \\
\hline 2006-2012 & 532.7 & 398 & 136.4 & 570 \\
\hline 2012-2018 & 107.4 & 238 & 131.2 & 551 \\
\hline
\end{tabular}

Table 1. Distribution of CORINE land cover classes among anthropogenic transformation groups (\%) between 1990 and 2018 in Hungary based on anthropogenic WRB diagnostics of soils

\begin{tabular}{c|c|c|c|c}
\hline Year & $\begin{array}{c}\text { No soils } \\
(0)\end{array}$ & $\begin{array}{c}\text { Natural or close to } \\
\text { natural soils (1) }\end{array}$ & $\begin{array}{c}\text { Soils with anthropogenic } \\
\text { features (2) }\end{array}$ & $\begin{array}{c}\text { Anthropogenic } \\
\text { soils (3) }\end{array}$ \\
\hline 1990 & 1.9 & 24.3 & 68.3 & 5.5 \\
2000 & 2.0 & 24.7 & 67.6 & 5.7 \\
2006 & 2.1 & 25.5 & 66.5 & 5.9 \\
2012 & 2.1 & 26.0 & 65.9 & 6.0 \\
2018 & 2.0 & 26.8 & 64.9 & 6.3 \\
\hline
\end{tabular}


LC polygons with decreased HI had in opposite larger area, but a smaller number. Therefore, averaged extent of polygons with these types of conversion varied between 0.45 $\mathrm{km}^{2}$ (2012-2018) and $1.34 \mathrm{~km}^{2}$ (2006-2012). To have an overview about the substantial LC changes of the conversions, we ranked the conversion types (coded by their CORINE code before and after the LC change) according to their frequency based on their area and number we found, separately for each period. LC conversions with decreased HI proved to be less diverse than with increased HI. Namely, 77 per cent per cent (2012-2018) to 93 per cent (2006-2012) of the area affected by LC changes with decreased HI belonged into the five most frequent types (Table 3), and the polygons in most frequent five types are 63-66 per cent respectively of the total number of polygons with LC changes with decreased HI. In case of LC conversions with decreased HI the initial LC was in most of the cases arable land, mineral extraction sites, complex cultivation patterns and vineyards. The conversions resulted transitional woodlands, shrubs, pastures and broad-leaved forests (see Table 3). It does not mean that at the moment of the conversion, the quality of landscape units suddenly changes, but this type of changes results inherently reduced level of disturbance and gives chances for the regeneration of the ecosystems and soils.

LC conversions with increased HI, therefore, show higher diversity, since the most frequent five types cover only 41 per cent (1990-2000), and 61 per cent (2000-2006) of the total area of them, and they mean only 25-37 per cent respectively of the total number of polygons with increased HI. When LC changes resulted increase in $\mathrm{HI}$ mostly arable lands, grasslands and pastures were turned into construction sites, mineral extraction sites, railways, and roads, industrial or commercial units (see Table 3). Also, when inland marshes were converted into water bodies, soils were devastated submerging under constant and higher water cover, even cancelled, according to definition of WRB, if submerged in more than 2 metre deep water.
For each period, both types of LC conversions (increased and decreased $\mathrm{HI}$ ) the most frequent five conversion types are listed in Table 3. Also, the summarized data show, that the number of polygons with LC changes affecting decreased $\mathrm{HI}$ are smaller $(1,676$ and $2,449)$, but the extent larger $\left(1,524.9 \mathrm{~km}^{2}\right.$ and $643 \mathrm{~km}^{2}$ ) as that of LC changes with increased $\mathrm{HI}$.

\section{Hotspots of changed HI}

As we mentioned in the data source and methods section, $1 \times 1 \mathrm{~km}^{2}$ grids were created. Using the grids, we prepared the hotspot analysis, based on the mentioned methodology earlier.

Hotspots were identified over the studied four periods. As before, we also highlighted the areas that contained the largest number in both the four periods and the total. To facilitate the research, these were summarized within the micro-regional boundaries and then we created the sequent table.

The spatial distribution of hotspots with increased HI is shown on Figure 5. Numerous hotspots proved to be hotspots not only in one studied period, but for more. Totally 2,449 between 1990 and 2018, in highest number on the Pest Plain (67), Csepel Plain (64) and Nagykállói-Nyírség (60) (Table 4). Most likely, the non-irrigated arable lands (211) are converted into construction sites (133) and industrial or commercial units (121), or road and railway network and associated lands (122). Furthermore, many pastures (231) are converted into construction sites (133) to. In the case of 1,012 hotspots number of LC change polygons with increased HI was in two periods higher than the respective threshold value of the hotspots. These are twofold hotspots, illustrated on Figure 5 with more intense colour. Triple hotspots were found in 223 grids and fourfold hotspot in 45. These multiple hotspots are shown with darker colour intensity in Figure 5. On the map, several aggregations of triple or fourfold hotsopts can be identified. The top 5 are 


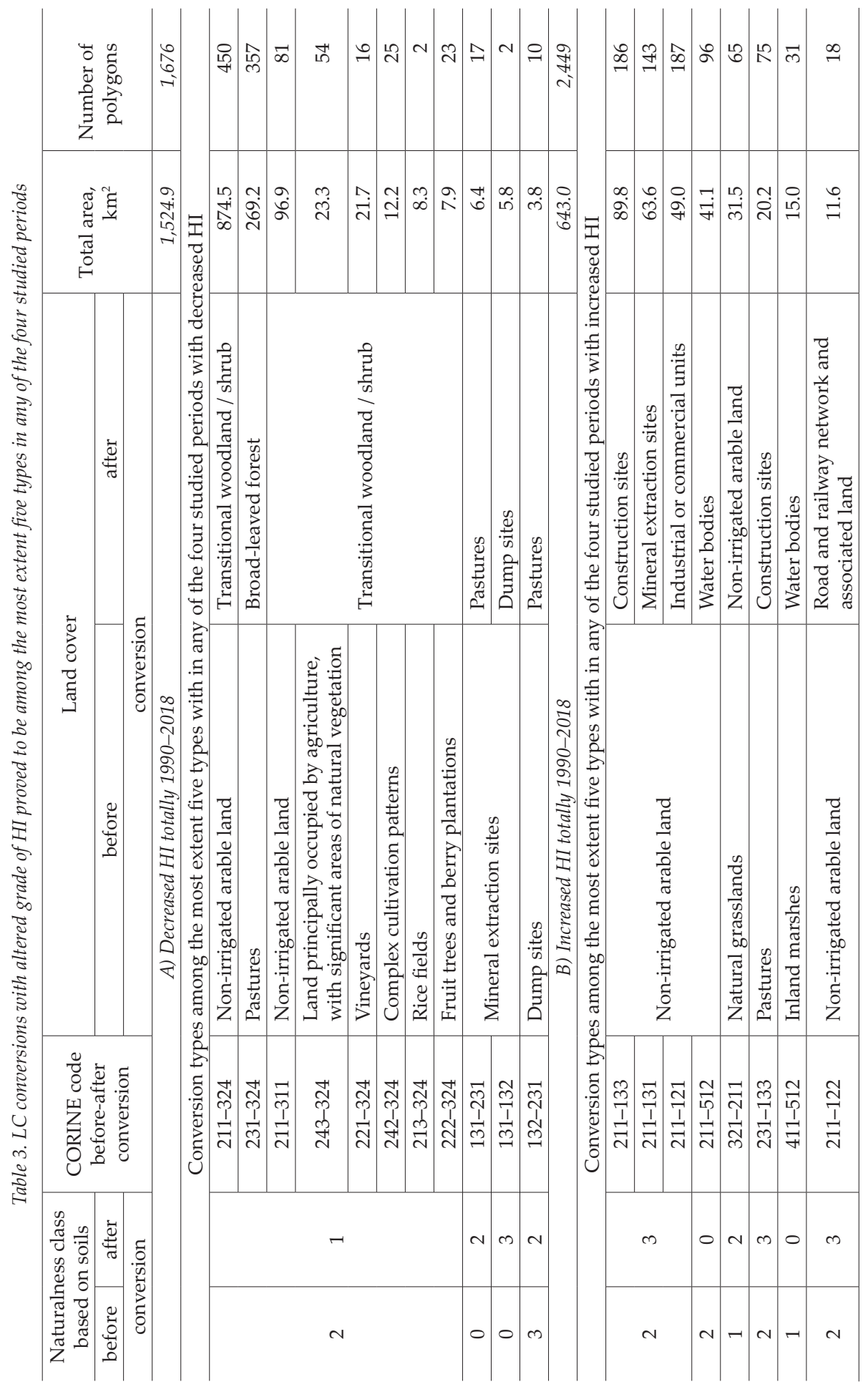




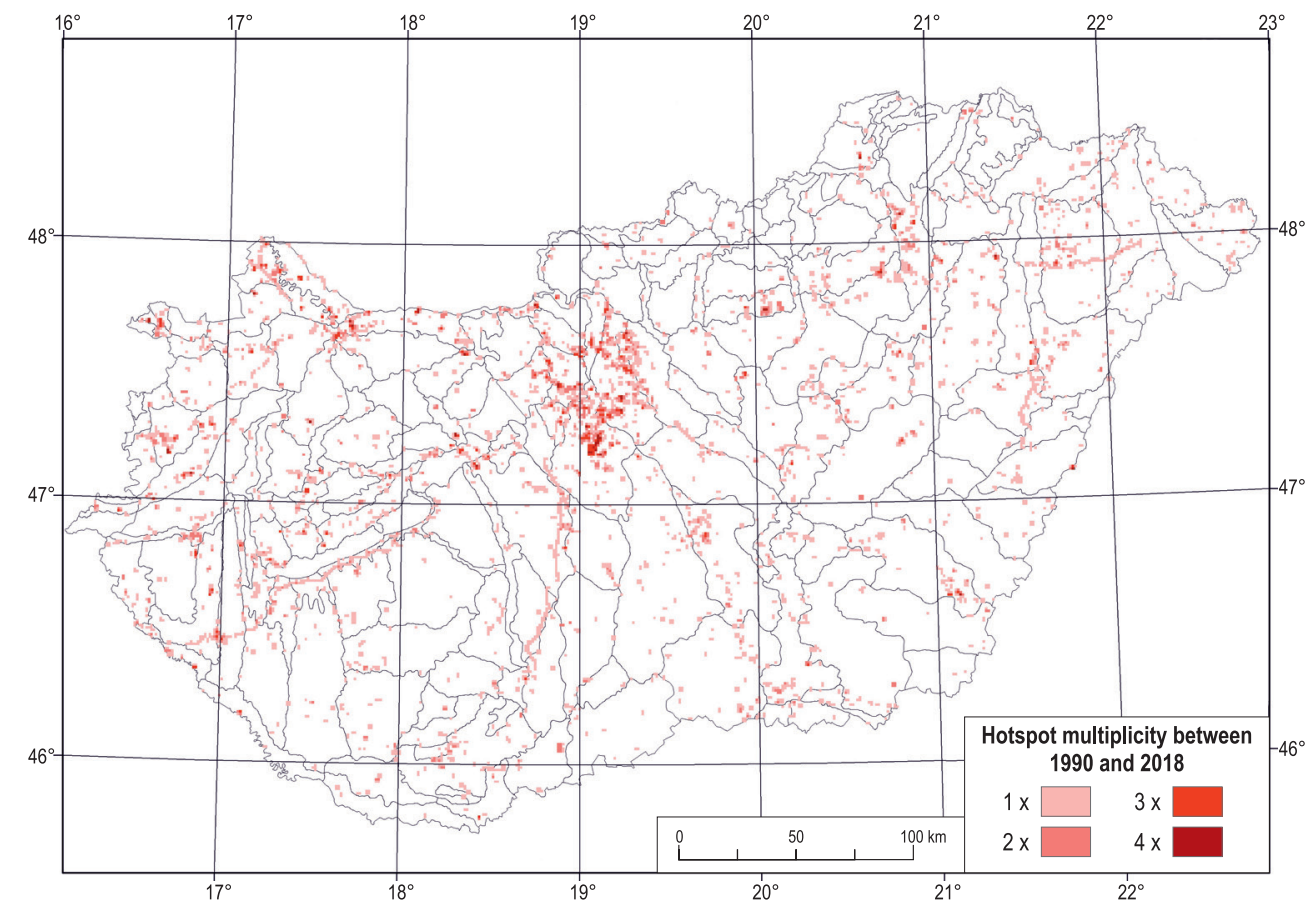

Fig. 5. Hotspots of increased human impact in Hungary based on LC changes 1990-2018

in the outskirts of Budapest highlighted by Kiskunlacháza, Bugyi, Délegyháza, besides in Győr and Bükkábrány.

In case of the LC changes with decreased HI the upper quartile of the number of polygons was 1 in all periods. This means, that all grids having at least two polygons with LC change showing decreased $\mathrm{HI}$ are regarded as a hotspot. The number of them is 593,447 , 401, and 238 in the above order. Totally 1,679 cells are regarded as a hotspot in any of the four-study periods between 1990 and 2018 (see Table 4). In largest number they occur on the Kiskunság Sand Ridge (38), MajsaSzabadka Sand Ridge (37) and NagykállóiNyírség (36). Figure 6 shows the location of further hotspots of decreased HI. Number of one-fold hotspots was found 2,379, two-fold hotspots were found in 135 grid cells and triple hotspots in 15, and no fourfold hotspot was found. The colour intensity also shows hotspot multiplicity in Figure 6. The most affected areas are in Izsák, Ásotthalom, Vatta and Nyírmihálydi. Usually, the non-irrigated arable lands (211) and pastures (231) and sometimes the agricultural types $(213,221$, $222,242,243)$ are converted into transitional woodlands or shrubs (324). Some of the hotspots are the mineral extraction sites (131) conversation into pastures (231).

\section{Discussion - Considerable effects of land cover conversions to soils}

Numerous studies analysed the CORINE datasets based on the changes in LC (Feranec, J. et al. 2007; Verburg, P.H. and Overmars, K.P. 2009; StÜrck, J. et al. 2015; Kuemmerle, T. et al. 2016; Plieninger, T. et al. 2016; FošKI, M. and Zavodnik LamovšEK, A. 2019), but the high number, small individual extent and high vari- 


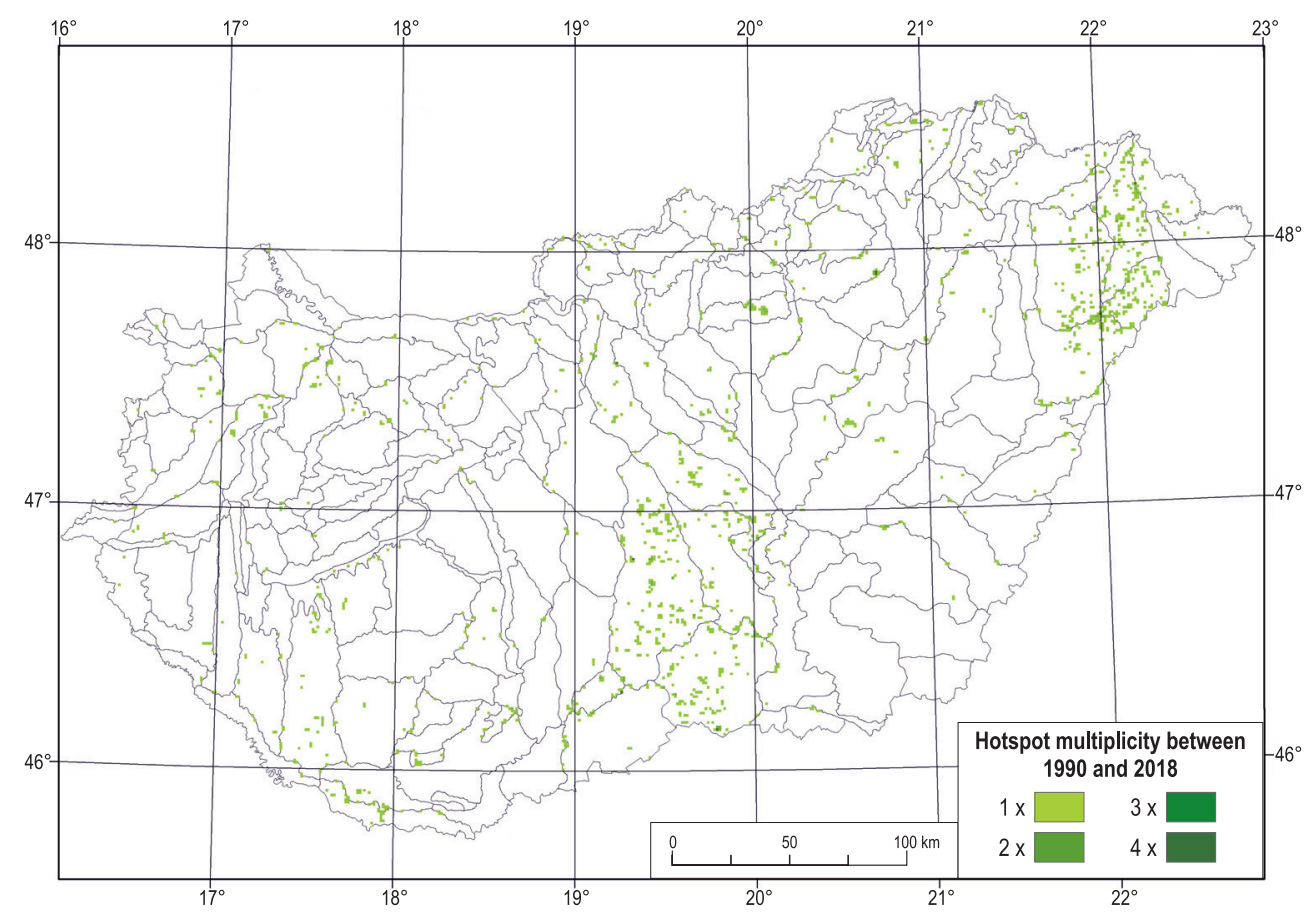

Fig. 6. Hotspots of decreased human impact in Hungary based on LC changes 1990-2018

ability of conversion types make the overview difficult and the evaluation of them complicated. We classified the conversions into three types based on the change of degree in HI, and evaluated their spatial extent considering their spatial frequency, using an auxiliary $1 \times 1 \mathrm{~km}$ grid to identify the hotspots of changes.

Also, in our earlier studies (Novák, T.J. and Incze, J. 2018; NovÁK, T.J. et al. 2019) we pointed on to the regional differences of landscape changes in Hungary on micro-and meso-region level. Considering these spatial units, quite frequently changes with increased and decreased HI were possible to observe within the same micro- or meso-regions, on the other hand, the exact identification of the changes was not possible. Therefore, this different approach: applying a grid and identification of hotspots proved to be more useful. It allowed the more precise delineation of areas with increased and decreased HI, and hotspots diversity among the four study periods highlighted the location of ongoing LC changes.

Our finding, that on the expense of the extent of LC classes with moderate HI both: the extent of LC classes with increased and the decreased HI impact was growing proved useful to point on increasing differentiation of LC. Regions with numerous hotspots of increased $\mathrm{HI}$ requires special management to moderate its negative consequences on soils, such as accelerated erosion, soil compaction, loss of organic carbon, mixing of soil horizons, soil sealing, soil loss appear concentrated, and affect urbanized areas. Highway constructions, industrial areas, and areas with intense peri-urban residential sprawl are typical places, where the LC conversions affects intense soil anthropization (FALKENBERG, J.A. et al. 2003; Ebels, L.J. et al. 2004; Csorba, P. 2005; Almajmaie, A. et al. 2017), so far that 
natural soils are no more possible to identify and even the substrate of soils are either artificial (construction waste composited from brick, slag, concrete, asphalt) or transported by humans (gravel, sand, rock). Besides their environmental risks, it makes these regions vulnerable against climate change, limiting the potential for resilient responses. Multiple hotspots of LC changes with increased HI warns to the ongoing degradation of soils in these areas. In contrast, regions with hotspots of decreased HI can count with organic material accumulation, carbon sequestration, regeneration of structure, increase of thickness of fertile soil layer (VAN ETVELde, V. and Antrop, M. 2009; SÁndor, G. et al. 2013; Horváth, A. et al. 2015).

That is true that these soil processes can compensate the unfavourable ones of hotspots of increased HI, but in many cases decreasing human impact on landscapes also requires special management and control, that must be considered. In case of decreasing $\mathrm{HI}$ on former industrial, mining, military and constructed areas a rewilding or renaturation can be related to the long-lasting release of pollutants into the groundwater or to the atmosphere, and therefore mean environmental risks besides of their regeneration processes.

Acknowledgements: The research was financed by the Higher Education Institutional Excellence Programme (NKFIH-1150-6/2019) of the Ministry of Innovation and Technology in Hungary, within the framework of the $4^{\text {th }}$ thematic programme of the University of Debrecen. Research work of Tibor József NovÁk was supported by the János Bolyai Research Scholarship of the Hungarian Academy of Sciences (BO/00448/17/10), by the ÚNKP-19-4-DE-129 (Tibor József NovÁk) and ÚNKP-19-3-I-DE-221 (Szabolcs BALOGH) new national excellence program of the Ministry for Innovation and Technology.

\section{REFERENCES}

Almajmaie, A., Hardie, M., Acuna, T. and Birch, C. 2017. Evaluation of methods for determining soil aggregate stability. Soil Tillage Research 167. 39-45.

Antrop, M. 2004. Landscape change and the urbanization process in Europe. Landscape and Urban Planning 67. (1-4): 9-26.
Ball, B.C., Guimarães, R.M.L., Cloy, J.M., Hargreaves, P.R., Shepherd, T.G. and McKenzie, B.M. 2017. Visual soil evaluation: a summary of some applications and potential developments for agriculture. Soil and Tillage Research 173. 114-124.

BALOGH, Sz., SüTő, L. and RózsA, P. 2018. Antropogén bolygatottság a Bükk-vidéken (Anthropogenic disturbance in the Bükk region). In Földrajzi Tanulmányok. Eds.: FazeKas, I., Kiss, E. and LÁzÁr, I., Debrecen, MTA DAB Földtudományi Szakbizottság, 239-241.

BALOGH, Sz., Ilyés, B., MÁrta, L. and NovÁk, T.J. 2019. Agrártájból agrármonokultúra - egy hajdúháti tájrészlet változásai (From the agricultural landscape to agricultural monoculture - changes in the landscape of Hajdúhát). In XII. Tájtörténeti Tudományos Konferencia. Tanulmánykötet. Eds.: Módosné, B.I., Csima, P., Hanyecz, K. and PÁlóczIHorvátr, A., Érd, Környezetkímélő Agrokémiáért Alapítvány, 16-21.

Baude, M., Meyer, B.C. and Schindewolf, M. 2019. Land use change in an agricultural landscape causing degradation of soil based ecosystem services. Science of the Total Environment 659. 1526-1536.

Bouma, J., Várallyay, G. and Batjes, N.H. 1998. Principal land use changes anticipated in Europe. Agriculture - Ecosystems \& Environment 67. (2-3): 103-119.

Ceauşu, S., Steve, C., Peter, H., Verburg, H.U., Kuechly, F.H., Luis, B. and Henrique, M.P. 2015. European wilderness in a time of farmland abandonment. In Rewilding European Landscapes. Eds.: Pereira, H. and Navaro, L., Cham, Springer, 22-45.

Csorba, P. 2005. Kistájaink tájökológiai felszabdaltsága a településhálózat és a közlekedési infrastruktúra hatására (The ecological fragmentation of the small landscape units of Hungary based of the settlement network and transport infrastructure). Földrajzi Értesítö / Hungarian Geographical Bulletin 54 (3-4): 243-263. (in Hungarian with English abstract)

Csorba, P. and Szabó, Sz. 2009. Degree of human transformation of landscapes: a case study from Hungary. Hungarian Geographical Bulletin 58. (2): 91-99.

DALE, V.H. and KLINE, K.L. 2013. Issues in using landscape indicators to assess land changes. Ecological Indicators 28. 91-99.

Dudal, R. 2005. The sixth factor of soil formation. Eurasian Soil Science 38. Supplement 1. 60-65.

Ebels, L.J., Lorio, R. and van der Merwe, C. 2004. The importance of compaction from an historical perspective. In Proceedings of the $23^{\text {rd }}$ Southern African Transport Conference (SATC 2004). Pretoria, South Africa, SATC Secretariat, 1-10. Available at http:// hdl.handle.net/2263/5680

Ellis, E.C. and Ramankutty, N. 2008. Putting people in the map: anthropogenic biomes of the world. Frontiers in Ecology and the Environment 6. 439-447. 
Ellis, E.C., Klein Goldewijk, K., Siebert, S., Lightman, D. and RAMANKUTtY, N. 2010. Anthropogenic transformation of the biomes, 1700 to 2000. Global Ecology and Biogeography 19.589-606.

Falkenberg, J.A., Persson, B., Hojsholt, U., Rokjaer, A., Wahid, M. and Andersen, J.S. 2003. Characterization of urban soil pollution. Report. Copenhagen, Danish Environmental Protection Agency 12. 138-150.

Feranec, J., Hazeu, G., Christensen, S. and Jaffraion, G. 2007. CORINE land cover change detection in Europe (case studies of the Netherlands and Slovakia). Land Use Policy 24. 234-247.

Forman, R.T.T. 1995. Land Mosaics: the Ecology of Landscapes and Regions. Cambridge, Cambridge University Press.

FošKi, M. and Zavodnik LAmovšek, A. 2019. Monitoring land-use change using selected indices. Acta geographica Slovenica 59. (2): 161-175.

FÖMI 2002. Az 1:50 000 léptékü országos CORINE Felszínboritási Projekt nómenklatúrája (Nomenclature of national CORINE Land Cover Project, scale 1:50,000). Version CLC50 1.42. 10.01.2002. Budapest, FÖMI.

Hill, M.O., Roy, D.B. and Thompson, K. 2002. Hemeroby, urbanity and ruderality: bio-indicators of disturbance and human impact. Journal of Applied Ecology 39. 708-720.

Horváth, A., Szúcs, P. and Bidló, A. 2015. Soil condition and pollution in urban soils: evaluation of the soil quality in a Hungarian town. Journal of Soils and Sediments 15. (8): 1825-1835.

INCZE, J. and NovÁK, T.J. 2016. Identification of extent, topographic characteristics and land abandonment process of vineyard terraces in the Tokaj-Hegyalja wine region between 1784 and 2010. Journal of Maps 12. (1): 507-513.

Kertész, Á. 2009. The global problem of land degradation and desertification. Hungarian Geographical Bulletin 58. (1): 19-31.

KLIJN, J.A. 2004. Driving forces behind landscape transformation in Europe, from a conceptual approach to policy options. In The New Dimensions of the European Landscape. Ed.: Jongman, R.H.G., Wageningen, Springer, 201-218.

Kuemmerle, T., Levers, C., Erb, K., Estel, S., Jepsen, M.R., Müller, D., Plutzar, C., Stürck, J., Verkerk, P.J., Verburg, P.H. and Reenberg, A. 2016. Hotspots of land use change in Europe. Environmental Research Letters 11. (6): 064020.

Lambin, E.F., Geist, H.J. and Rindfuss, R.R. 2006. Local processes with global impacts. In Land-Use and Land-Cover Change: Local Process and Global Impacts. Eds.: Lambin, E.F. and Geist, H.J., Berlin, Springer, 1-8.

LundberG, A. 2018. Recent methods, sources and approaches in the study of temporal landscape change at different scales - a review. Hungarian Geographical Bulletin 67. (4): 309-318.

Mari, L. and Mattányi, Zs. 2002. Egységes európai felszínborítási adatbázis a CORINE Land Cover program (A uniform European land cover database the CORINE Land Cover Program). Földrajzi Közlemények 126. (1-4): 31-38.

MAri, L. 2010. Tájváltozás elemzése a CORINE adatbázisok alapján (Analysis of landscape changes using CORINE database). In Tájváltozás értékelési módszerei a XXI. században. Tudományos konferencia és mühelymunka tanulmányai. Eds.: SzIlassi, P. and Henits, L., Szeged, SZTE, 226-234.

Navarro, L. and Pereira, H. 2015. Rewilding abandoned landscapes in Europe. In Rewilding European Landscapes. Eds.: Navarro, L. and Pereira, H., International Publishing, Cham, Springer, 3-23.

Novák, T.J., Incze, J. and Rózsa, P. 2013. Quantifying anthropogeomorphological transformation by using the concept of "hemeromorphy" - a case study from Hungary, In $8^{\text {th }} I A$ International Conference on Geomorphology. Abstract Book. Eds.: Mercier, D. and VAnara, N., Paris, IAG, 466-466.

Novák, T.J. and Tóth, Cs.A. 2016. Development of erosional microforms and soils on semi-natural and anthropogenic influenced solonetzic grasslands. Geomorphology 254. 121-129.

NovÁk, T.J. and Incze, J. 2018. Antropogén hatások becslése hazai talajokban felszínborítási adatok és WRB diagnosztika alapján (Estimation of anthropogenic effects in domestic soils based on land cover data and WRB diagnostics). Agrokémia és Talajtan 67. (2): 179-197.

Novák, T.J., BAlogh, Sz. and Incze, J. 2019. Hazai tájváltozások és térbeli különbségeik értékelése felszínborítási és talajadatok alapján (Estimation of Hungarian landscape changes and their spatial differences based on land cover and soil data). In XII. Tájtörténeti Tudományos Konferencia. Tanulmánykötet. Eds.: Módosné, B.I., Csima, P., Hanyecz, K. and Pálóczi-Horváth, A., Érd, Környezetkímélő Agrokémiáért Alapítvány, 153-159.

Plieninger, T., Draux, H., Fagerholm, N., Bieling, C., Bürgi, M., Kizos, Th., Kuemmerle, T., Primdahl, J. and Verburg, P.H. 2016. The driving forces of landscape change in Europe: A systematic review of the evidence. Land Use Policy 57. 204-214.

Sándor, G., Szabó, Gy., Charzyński, P., Szynkowska, E., Novák, T.J. and Świtoniak, M. 2013. Technogenic soils in Debrecen. In Technogenic Soils. Eds.: Charzyński, P., Markiewicz, M. and Świtoniak, M., Toruń, Polish Society of Soil Science, 35-74.

Stürck, J., Levers, Ch., vaN der ZANDEN, E.H., Schulp, C.J.E., Verkerk, P.J., Kuemmerle, T., Helming, J., Lotze-Campen, H., Tabeau, A., Popp, A., Schrammeijer, E. and Verburg, P. 2015. Simulating and delineating future land change trajectories 
across Europe. Regional Environmental Change 18. (3): 733-749.

Szilassi, P., Bata, T., Szabó, Sz., Czúcz, B., Molnár, Zs. and Mezôsı, G. 2017. The link between landscape pattern and vegetation naturalness on a regional scale. Ecological Indicators 81. 252-259.

Van Etvelde, V. and Antrop, M. 2009. Indicators for assessing changing landscape character of cultural landscapes in Flanders (Belgium). Land Use Policy 26. 901-910.
Verburg, P.H. and Overmars, K.P. 2009. Combining top-down and bottom-up dynamics in land use modelling: exploring the future of abandoned farmlands in Europe with the Dyna-CLUE model. Landscape Ecology 24. 1167-1181. 
